\title{
Pharmacognostic and Phytochemical Investigations of Bahunia Variegata Leaves (Kovidra)
}

\author{
Pallavi S More A* and Baheti AM \\ School of Pharmacy, MIT World Peace University, India
}

*Corresponding author: Pallavi S More Adate, School of Pharmacy, MIT World Peace University, India, Tel: 919881443297; Email: pallaviadate@gmail.com

\section{Research Article}

Volume 4 Issue 2

Received Date: July 11, 2020

Published Date: August 17, 2020

DOI: $10.23880 /$ ipcm-16000205

\section{Abstract}

Bauhinia variegata L belonging to the Caesalpinioideae family, commonly called as kovidra in sanskrit and kachnar in hindi. Kovidra is a medium sized deciduous tree mostly observed at altitude 1300 to 1800 in Himalayas. The plant is extensively utilized by the tribals all over in India and accepted in medicinal systems like Ayurveda, Unani and Homoeopathy. Secondary metabolites like carbohydrates, tannins, alkaloids, and flavonoids are present in Bauhinia variegata plant. The aim of the current research is to develop different pharmacognostic and phytochemical analysis for the evaluation of leaf of this plant. Microscopy, Phytochemical analysis of leaf drug was performed and results were maintained. In microscopical view of Bauhinia variegata leaf, the presence of thin walled epidermis, spongy paranchymatous cells, plenty of solitary calcium oxalate crystals, unicellular and multicellular covering trichomes were observed. Phytochemical tests indicated the occurrence of flavonoids, tannins, steroids and phenols etc. Further physicochemical analysis such as extractive value was determined which includes petroleum ether soluble extractive value, chloroform, methanol, and aqueous soluble extractive values. The results obtained from standardization of leaf drug recognized the macro and microscopical parameters, physicochemical parameters. Fluorescence analysis of leaf drug distinguishes the authenticity of plant drug; therefore these techniques are helpful for rapid recognition of crude drug. The outcome of the research study possibly will be helpful in setting investigative indices for the identification and grounding of a monograph of the plant drug.

Keywords: Bauhinia Variegata; Leaf Microscopy; Physicochemical Analysis; Phytochemical Screening; Fluorescence Study

\section{Introduction}

Bauhinia variagata belonging to the family fabaceae and sub family caesalpinioideae is frequently identified as mountain ebony in English, kachnar in hindi and raktkanchan in marathi. It is inhabitant to moderate and tropical Indian Subcontinent, Southeastern countries of Asia and China [1]. Approximately 15 species of this genus found in India [2]. Kanchnar is well described in ancient ayurveda and its stem, bark \& flowers are widely used as remedy in a variety of formulations like kanchanar guggul. Bark of kanchanar is used in disorders like lymphadenopathy, goitre, tumor, and kapha-Pitta dosha disorders while flowers are used to treat pittaghna i.e. pitta dosha, dysfunctional uterine bleeding, and kshyaghna i.e. tuberculosis. Further it is also practiced by ayurvedic practitioners in management of various carcinomas [3]. The tribal communities of diverse areas use this plant for the curing skin diseases such as leucoderma and leprosy, wounds, ulcers, cough, dysentery, snakebite, tumours, flatulence, indigestion, piles [4]. Reported phytochemical constituents of the Bauhinia variegata are lupeol, tannins, kaempferol-3glucoside, amides, carbohydrates, crude protein, vitamin $\mathrm{C}$, fibers, calcium, phosphorus, rutin, quercetin, apigenin, apigenin-7-0-glucoside, dotetracont-15en-9-ol and heptatriacontan-12,13-diol [5-7].

Plant drugs usually adulterated with similar looking drugs therefore it is mandatory to use plant drugs after standardization for research work. This research paper deals with macroscopoical characteristics of kachnar as well 


\section{International Journal of Pharmacognosy \& Chinese Medicine}

as microscopy of leaves of kachnar plant. In addition it also consists of phytochemical screening of successive extracts of the kachnar plant [8].

\section{Materials and Methods}

\section{Collection of Plant Material}

Leaves of Bauhinia variegate were collected from Vadgaon area of Pune district in Maharashtra in the month of September and October 2019, and the samples were authenticated at the Agharkar Research Institutes Pune. The specimen voucher was preserved as herbarium in university.

\section{Macroscopical and Microscopical Evaluation}

After botanical authentication of Bauhinia variegata plant, the macroscopic evaluation of the leaves was carried out as per standard procedure. Size \& shape, colour, surfaces, venation, apex, margin, base, lamina, texture, and organoleptic properties were examined $[9,10]$. Fresh leaves were preferred for the microscopical examination. Transverse sections were taken out by free hand section cutting method. Various temporary and permanent slides of the microscopical sections of the specimen were prepared and examined microscopically [11].

\section{Powder Drug Investigation}

The powder leaf drug was independently boiled with $5 \%$ phloroglucinol, 5\% alcoholic potassium hydroxide and 5\% Chloral hydrate solution, iodine- iodide for starch, sudan IV for liphophilic substances and in ruthenium red for presence of mucilage [12]. In addition to that quantitative microscopy of Bauhinia variegata leaves were carried out. For that purpose fresh leaf was independently mounted in glycerin to determine the presence of lignified cells, calcium oxalate crystals and starch grains.

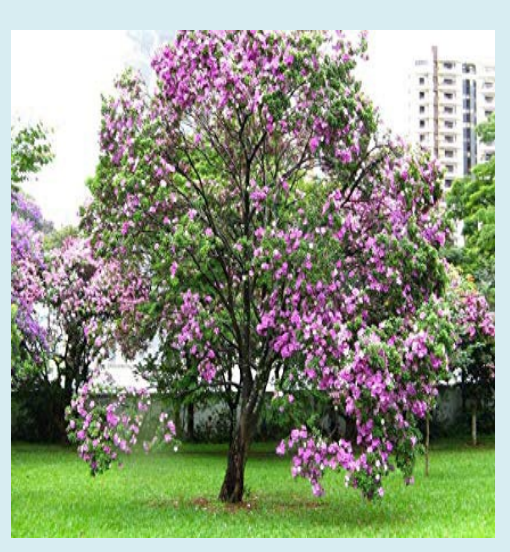

Figure 1: Bauhinia variegata Tree.

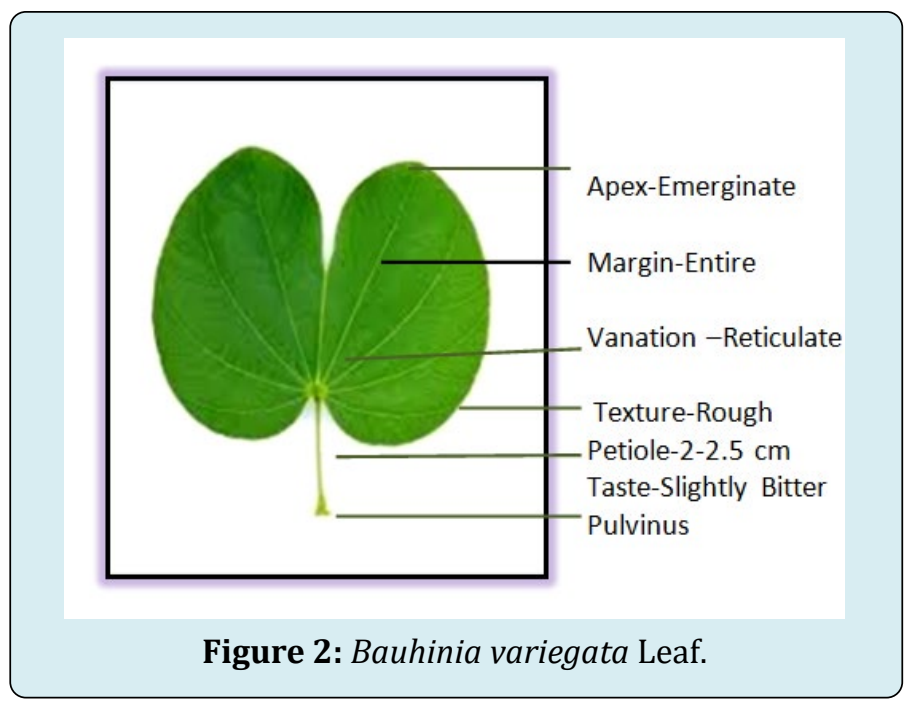

\section{Physicochemical Parameters}

$1 \mathrm{gm}$ of dried powdered leaves was used for total value determination by keeping it in muffle furnace at $400^{\circ} \mathrm{C}$ temperatures. Total ash was studied for different inorganic constituents like fraction of total ash, acid- insoluble ash, water soluble ash, sulphated ash and loss on drying were calculated as per the Indian Pharmacopoeia [13]. Successive extracts of Bauhinia variegata leaves were prepared for the examination of extractive values of the leaves. Powdered leaves were further analyzed for fluorescence analysis according to the standard methods $[14,15]$.

\section{Successive Solvent Extraction}

Successive extraction of leaf drug was carried out by using powder of dried Bahaunia leaves along with organic solvents. $100 \mathrm{gm}$ powdered leaves were subjected to continuous soxhlet extraction unit with various organic solvents as per polarity such as petroleum ether (60-80), chloroform, and methanol and water respectively [16].

\section{Phytochemical Investigation}

The obtained successive extracts were further concentrated under vacuum using rotary vacuum evaporator, dried and weighed for calculating percentage yield. Phytochemical analysis of each extract was performed for presence of secondary metabolites, viz. proteins, carbohydrates, tannins, glycosides, flavonoids, saponins, fats and amino acids by usual prescribed methods $[17,18]$.

\section{Fluorescent Studies of Powder Drugs}

The fluorescence analysis of powdered drug was carried out by UV Spectroscopic method under $254 \mathrm{~nm}$ and $365 \mathrm{~nm}$ after treatment with various reagents [19]. 


\section{International Journal of Pharmacognosy \& Chinese Medicine}

\section{Total Phenolic Content}

Powdered leaves were studied for concentration of phenolic compounds with the help colorimetric method of Folin-Ciocalteu. The absorbance was calculated at $765 \mathrm{~nm}$ against blank, using Shimadzu UV spectrophotometer. The total polyphenolic content was thus measured as gallic acid equivalents and expressed in \% as gallic acid [20].

\section{Total Tannin Estimation}

Total tannin content of Bauhinia variegata leaf extract was estimated with Folin-Denis method. The absorbance was calculated at $760 \mathrm{~nm}$ using Shimadzu UV spectrophotometer. Experiment was performed in triplicate and the estimated quantity was measured from calibration curve obtained with tannic acid. Total tannin content was expressed as g / $100 \mathrm{~g}$ of tannic acid equivalent [21].

\section{Results and Discussion}

\section{Macroscopical Evaluation}

The leaves of Bauhinia variegata plant is of fresh green in colour on both side in fresh state and light brown in dry condition. Size and shape of leaves are 12-14 in length and $13-15 \mathrm{~cm}$ in breadth, cleft $1 / 4$ to $1 / 3$ of the way down into lobes are divided in to 2 obtuse portions, base is pulvinus with ridged petiolate, linear- lanceolate with entire margin along with presense of soft stipules. Apex of the leaf is wide and emarginated. The outer surface of leaf is moderately rough. In addition to that leaf showcased reticulate and palm-divergent venations as shown in figure 2. Taste of leaf is bitter to some extent and having characteristic of odour.

\section{Microscopical Characteristics}

In the transverse section of Bauhinia variegata leaf (Figure 3) mesophyllic stratum in the laminar portion of leaf showcased the presence of palisade cells in 2 to 3 layers below the upper epidermis and spongy parenchyma above the lower epidermis. Calcium oxalate crystals are present throughout the mesophyllic membrane in prismatic manner. Midrib is slightly concave in shape. Midrib contains well developed vascular bundle at the centre surrounded by sclerenchymatic cells. The presence of the xylem at the upper side and phloem at the lower side of vascular bundle could be seen. Collenchymatous cells are scattered in between upper and lower epidermis along with calcium oxalate crystals as characteristic feature. In addition to that covering trichomes are present with peculiarity i.e. they are unicellular and multicellular uniseriate as well as unicellular sessile. They are majorly observed on the lower epidermis than upper epidermis.

\section{Powder Microscopy}

In the powder microscopy, prism shaped calcium oxalate crystals, long multicellular uniseriate trichomes; lignified spiral xylem vessels and fraction of epidermal cells were observed.

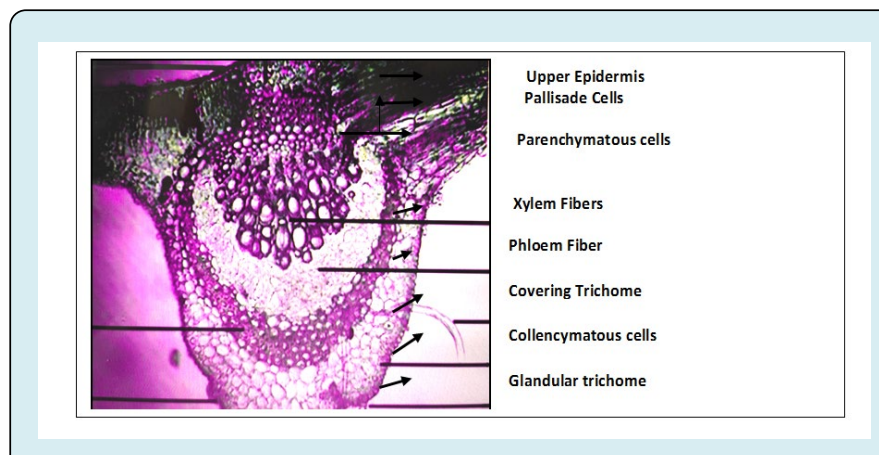

Figure 3: Transverse Section of Bauhinia variegata L. Leaf.

\section{Physicochemical Parameters}

The percentage of total ash, acid insoluble ash, water soluble ash and loss on drying are summarized in Table 1. Successive solvent extraction values in various organic solvent were calculated as petroleum ether $3.15 \%$, chloroform $4.30 \%$, methanol $6.86 \%$ and water is $8.90 \%$ as shown in Table 2.

\begin{tabular}{|c|c|c|}
\hline S.No. & Parameters & Values (\%) \\
\hline 1 & Total Ash Value & 8.15 \\
\hline 2 & Water insoluble ash value & 6.25 \\
\hline 3 & Water soluble ash value & 2.55 \\
\hline 4 & Acid insoluble ash value & 5.4 \\
\hline 5 & Loss on drying & 6.55 \\
\hline
\end{tabular}

Table 1: Physiochemical Parameters of B.Variegata L.

\begin{tabular}{|c|c|c|}
\hline Type of Extract & $\begin{array}{c}\text { Colour of } \\
\text { extract }\end{array}$ & $\begin{array}{c}\text { Extractive value } \\
\mathbf{\%} \text { w/w (Mean a } \\
\mathbf{\pm} \text { SEM) }\end{array}$ \\
\hline $\begin{array}{c}\text { Petroleum ether } \\
\text { soluble }\end{array}$ & $\begin{array}{c}\text { Sticky Greenish- } \\
\text { Brown }\end{array}$ & $3.15 \pm 0.05$ \\
\hline Chloroform soluble & Sticky Greenish & $4.30 \pm 0.05$ \\
\hline Methanol soluble & Light Brown & $6.86 \pm 0.05$ \\
\hline Water soluble & $\begin{array}{c}\text { Water soluble } \\
\text { Brown }\end{array}$ & $8.90 \pm 0.05$ \\
\hline
\end{tabular}

Table 2: Extractive value of Successive Leaf Extracts of B.Variegata L. 


\section{International Journal of Pharmacognosy \& Chinese Medicine}

\section{Phytochemical Analysis}

The results confirmed presence of alkaloids, flavonoids, saponin, tannins, steroids, phenols and carbohydrates in Bauhinia variegata L leaf. The presences of variety of secondary metabolites in various organic and aqueous extracts are summarized in Table 3.

\begin{tabular}{|c|c|c|c|c|c|}
\hline Sr. No & Phytochemical tests & $\begin{array}{c}\text { Petroleum ether } \\
\text { Extract }\end{array}$ & $\begin{array}{c}\text { Chloroform } \\
\text { Extract }\end{array}$ & Methanolic Extract & Aqueous Extract \\
\hline 1 & Carbohydrates & + & + & - \\
\hline 2 & Saponins & ++ & - & - \\
\hline 3 & Glycosides & - & - & + \\
\hline 4 & Tannins & - & - & ++ \\
\hline 5 & Flavonoids & - & - & ++ \\
\hline 6 & Phenols & - & + & + \\
\hline 7 & Alkloides & - & + & - \\
\hline 8 & Fixed Oil & + & - & - \\
\hline
\end{tabular}

Table 3: Phytochemical Analysis of Successive Leaf Extracts of B.Variagata L.

\section{Fluorescence Analysis}

Result of fluorescence analysis of Bauhinia variegata leaf powder was observed at UV short wavelength and long wavelength i.e at 254 and $366 \mathrm{~nm}$ respectively. The response at different wavelengths was recorded and summarized in Table 4.

\begin{tabular}{|c|c|c|c|c|}
\hline S. No & $\begin{array}{l}\text { Powdered drug with } \\
\text { Different Reagent }\end{array}$ & $\begin{array}{c}\text { Observation under } \\
\text { visible light }\end{array}$ & $\begin{array}{c}\text { Observation Under UV } \\
254 \mathrm{~nm}\end{array}$ & Observation Under UV 366nm \\
\hline 1 & Drug Powder & Greenish Brown & Green & Light Brown \\
\hline 2 & Drug+ Pet Ether & Slight Green & Green & Slightly Brown \\
\hline 3 & Drug+5\%Iodine & Light Brown & Light Green & Deep Green \\
\hline 4 & Drug+5\% FeCl3 & Dark Brown & Green & Deep Green \\
\hline 5 & Drug+ 1M H2SO4 & Green & Light Green & Brownish \\
\hline 6 & Drug + Dilute Ammonia & Light Green & Fluorescent Green & Brownish \\
\hline 7 & Drug+ Methanol & Dark Green & Green & Brownish \\
\hline 8 & Drug+ KOH & Yellowish Green & Light Green & Blackish Brown \\
\hline 9 & Drug+ Picric Acid & Light Green & Light Green & Dark Green \\
\hline 10 & Drug+ Chloroform & Light Green & Light Green & Brownish \\
\hline
\end{tabular}

Table 4: Fluorescence Analysis of B. Variegata Linn. Leaf Powder with different reagents observed under UV-radiation.

\section{Total Phenolic and Tannin Content}

The total polyphenolic content was thus measured as gallic acid equivalents and obtained $82.71 \pm 0.5$ per $100 \mathrm{gm}$ of gallic acid. Total tannin content was obtained $89.25 \pm 5.25 /$ $100 \mathrm{~g}$ of tannic acid equivalent.

\section{Conclusion}

Bauhinia variagata Linn is the traditional therapeutic plant with a great potential and acts as remedy to cure diverse ailments. The present research work was focused on performance of standardization parameters for recognition of original drug. These analytical techniques include macroscopical \& microscopical examination idiosyncratic identification of drug. In addition to that physicochemical analysis was performed with parameters like ash values, loss on drying, extractive values. Further, qualitative phytochemical investigation was also performed on successive leaf extracts. These standardization parameters were studied and data obtained possibly will be helpful for the quality assessment of plant drug material, secondly, this data would be helpful for determination of adulterated and 


\section{International Journal of Pharmacognosy \& Chinese Medicine}

substituted drug. The pharmacognostic approach of study of Bauhinia variagata Linn; sets qualitative and quantitative standards. It would be definitely establishes distinctiveness, eminence and purity of this plant drug in intimately correlated species.

\section{References}

1. Gautam S (2012) Bauhinia variegata Linn: All Purpose utility and medicinal tree. Forestry Bulletin 12(2): 6164 .

2. Kirtikar KRBB, Basu BD (1999) Indian medicinal plants. Indian Medicinal Plants, pp: 892-90.

3. Nariyal V, Sharma P (2018) Kanchnar (bauhinia variagata) as a medicinal herb: a systematic review. Int J Adv Res 5(9): 587-591.

4. Santosh S, Ashwani K (2012) Tribal uses of medicinal plants of Rajashthan: Kachnar. Int J Life Sci Pharm Res 2(4): 69-76.

5. Sharma DD, Chawla MS, Negi SS (1968) Chemical composition and nutritive value of bamboo (Bamboosa arundinaceae) and'Kachnar'(Bauhenia variegata) tree leaves. Journal of Research-Punjab Agricultural University 5: 253-258.

6. Spilkova J, Hubik J (1992) The biological actions of flavonoids. II. Pharmazie in unserer Zeit 21(4): 174-182.

7. Singh RS, Pandey HS (2006) Two new long chain compounds from Bauhinia variegata Linn 45(9): 21512153.

8. Singh N, Singh A, Pabla D (2019) A review on medicinal uses of Bauhinia Variegata Linn. PharmaTutor 7(6): 1217.

9. William E (2009) Trease and Evans Pharmacognosy. Saunders. Elsevier, Edinburgh London, pp: 347-356.

10. Pahwa S, Mazumder R, Bhattacharya S, Kumari S, Mazumder A, et al. (2010) Pharmacognostical and Phytochemical Evaluation of the leaves of Bauhinia purpurea Linn. Ancient science of life 30(2): 28-32.
11. Khandelwal K (2008) Practical pharmacognosy. Pragati Books Pvt Ltd, pp: 1-2.6.

12. Pharmacopoeia I (1996) Government of India, ministry of health and family welfare. Delhi: Controller of Publications 2(35): 52.

13. Kokoski CJ, Kokoski RJ, Slama FJ (1958) Fluorescence of powdered vegetable drugs under ultraviolet radiation. Journal of the American Pharmaceutical Association 47(10): 715-717.

14. Chase Jr, Pratt R (1949) Fluorescence of powdered vegetable drugs with particular reference to development of a system of identification. Journal of the American Pharmaceutical Association 38(6): 324-331.

15. Pharmacopoeia I (1985) Controller of publications. New Delhi, pp: 310.

16. Khan N, Pande M, Jha KK (2019) Preliminary Pharmacognostic Evaluations and Phytochemical Studies on Leaves of Bauhinia Racemosa (Sonapatti). Int J Biochem Pharmacol 1(1): 12-15.

17. Wagner H, Bladt S (1996) Plant drug analysis: a thin layer chromatography atlas. Springer Science \& Business Media, pp: 360-364.

18. Harborne JB (1998) Phytochemical methods. $3^{\text {rd }}$ (eds.) Chapman and Hall. New York, pp: 90.

19. Kadam PV, Deoda RS, Shivatare RS, Yadav KN, Patil MJ (2012) Pharmacognostic, phytochemical and physiochemical studies of Mimusops Elengi Linn stem bark (Sapotaceae). Der Pharmacia Lettre 4(2): 607-613.

20. Singleton VL, Rossi JA (1965) Colorimetry of total phenolics with phosphomolybdic-phosphotungstic acid reagents. American journal of Enology and Viticulture 16(3): 144-158.

21. Dubois M, Gilles KA, Hamilton JK, Rebers PT, Smith F (1956) Colorimetric method for determination of sugars and related substances. Analytical chemistry 28(3): 350356. 